\title{
Acute sedimentation response to rainfall following the explosive phase of the 2008-2009 eruption of Chaitén volcano, Chile
}

\author{
Thomas C. Pierson • Jon J. Major • Álvaro Amigo • \\ Hugo Moreno
}

Received: 1 November 2012 /Accepted: 14 April 2013 /Published online: 28 April 2013

(C) The Author(s) 2013. This article is published with open access at Springerlink.com

\begin{abstract}
The 10-day explosive phase at the start of the 2008-2009 eruption of Chaitén volcano in southern Chile $\left(42.83^{\circ} \mathrm{S}, 72.65^{\circ} \mathrm{W}\right)$ blanketed the steep, rain-forestcloaked, $77-\mathrm{km}^{2}$ Chaitén River drainage basin with 3 to $>100 \mathrm{~cm}$ of tephra; predominantly fine to extremely fine rhyolitic ash fell during the latter half of the explosive phase. Rain falling on this ash blanket within days of cessation of major explosive activity generated a hyperconcentratedflow lahar, followed closely by a complex, multi-day, muddy flood (streamflow bordering on dilute hyperconcentrated flow). Sediment mobilized in this lahar-flood event filled the Chaitén River channel with up to $7 \mathrm{~m}$ of sediment, buried the town of Chaitén (10 km downstream of the volcano) in up to $3 \mathrm{~m}$ of sediment, and caused the lower $3 \mathrm{~km}$ of the channel to avulse through the town. Although neither the nature nor rate of the sedimentation response is unprecedented, they are unusual in several ways: (1) Nearly 70
\end{abstract}

\footnotetext{
Editorial responsibility: V. Manville

T. C. Pierson $(\varangle) \cdot$ J. J. Major

Cascades Volcano Observatory, U.S. Geological Survey, 1300 S.E.

Cardinal Court, Ste. 100,

Vancouver, WA, USA

e-mail: tpierson@usgs.gov

J. J. Major

e-mail: jjmajor@usgs.gov

Á. Amigo $\cdot$ H. Moreno

Servicio Nacional de Geología y Minería, Programa de Riesgos

Volcánicos, Merced 22, oficina 701,

Santiago, Chile

Á. Amigo

e-mail: aamigo@sernageomin.cl

H. Moreno

e-mail: hmoreno@sernageomin.cl
}

percent of the aggradation (almost $5 \mathrm{~m}$ ) in the 50-70-mwide Chaitén River channel was caused by a lahar, triggered by an estimated $20 \mathrm{~mm}$ of rainfall over a span of about $24 \mathrm{~h}$. An additional $2 \mathrm{~m}$ of aggradation occurred in the next 24 $36 \mathrm{~h}$. (2) Direct damage to the town was accomplished by the sediment-laden water-flood phase of the lahar-flood event, not the lahar phase. (3) The volume of sediment eroded from hillslopes and delivered to the Chaitén River channel was at least $3-8 \times 10^{6} \mathrm{~m}^{3}$-roughly $15-40 \%$ of the minimum tephra volume that mantled the Chaitén River drainage basin. (4) The acute sedimentation response to rainfall appears to have been due to the thickness and fineness of the ash blanket (inhibiting infiltration of rain) and the steepness of the basin's hillslopes. Other possible factors such as the prior formation of an ash crust, development of a hydrophobic surface layer, or large-scale destruction of rain-intercepting vegetation did not play a role.

Keywords Chaitén · Lahar · Muddy flood · Volcaniclastic sedimentation · Channel aggradation · Tephra fall · Rainfall runoff

\section{Introduction}

Explosive volcanic eruptions can drastically alter hydrologic regimes and sediment delivery in drainage basins on or near source volcanoes (e.g., Chinen 1986; Major and Mark 2006; Gran et al. 2011). Eruption-generated mass flows and tephra fall can remove, bury, or damage vegetation (e.g., Swanson and Major 2005; Swanson et al. 2013), mantle broad areas of terrain with tephra sufficiently fine to decrease soil infiltration capacity (e.g., Leavesley et al. 1989; Ikeya et al. 1996; Yamakoshi et al. 2005), and load rivers with large 
quantities of volcaniclastic sediment (e.g., Newhall and Punongbayan 1996; Miyabuchi 1999; Major et al. 2000; Pallister et al. 2013b). As a result, volcanically disturbed drainage basins are subject to altered runoff and streamflow (e.g., Leavesley et al. 1989; Yamakoshi and Suwa 2000; Major and Mark 2006) and to exceptional, and sometimes prolonged, erosion and sediment transport (e.g., Waldron 1967; Chinen, 1986; Thouret et al. 1998; Lavigne et al. 2000; Major et al. 2000; Hayes et al. 2002; Major 2004; Gran et al. 2011; Pierson et al. 2011).

High-concentration sediment-water flows (lahars and muddy floods) commonly emanate from volcanically disturbed drainage basins both during and after eruptions (e.g., Kadomura et al. 1983; Imagawa 1986; Rodolfo and Arguden 1991; Newhall and Punongbayan 1996; Lavigne et al. 2000; Barclay et al. 2007; Capra et al. 2010). Lahars are commonly the first water-mobilized flows to affect vulnerable downstream communities during and following eruptions, and they also tend to cause the greatest damage (e.g., Waldron 1967; Major et al. 1996; Rodolfo et al. 1996; Lavigne et al. 2000; Capra et al. 2010). Those not triggered by snowmelt, glacier outbursts, lake breakouts, or transformations of debris avalanches are typically triggered by rainfall following tephra deposition or basin disturbance by other volcanic processes.

The lag time between drainage-basin disturbance and rainfall-generated lahar activity can vary from nil (syneruptive lahars) to several years (posteruptive lahars), but it is not unusual for months to years to pass before maximum levels of aggradation from rain-triggered lahars and excessive fluvial sedimentation are experienced downstream of a volcano (Waldron 1967; Miyabuchi 1999; Major et al. 2000; Hayes et al. 2002; Gran et al. 2011; Pierson et al. 2011). At Mount Pinatubo, for example, rain-triggered lahars and floods occurred during the June 15, 1991 eruption itself, but more profound geomorphic changes due to ongoing erosion and downstream channel aggradation continued for more than a year after the eruption (Newhall and Punongbayan 1996).

The initial sedimentation response to the 2008-2009 eruption of Chaitén volcano in northern Patagonia (Chile) provides an example of the sensitivity of landscapes to volcanic disturbance, and it demonstrates that raintriggered lahars and sediment-laden floods are hazards that can quickly endanger vulnerable downstream communities. The early explosive phase of the 2008-2009 eruption produced a widespread fall of pumiceous tephra (particles to at least $10 \mathrm{~cm}$ diameter), but the upper layers of the tephra blanket were dominated by fine to extremely fine ash $(0.250$ to $<0.063 \mathrm{~mm}$ ) (White and Houghton 2006; Alfano et al. 2011; J. Castro, Johannes Gutenberg Universität Mainz, 2012, written communication). Virtually all of the Chaitén River (Río Chaitén, or sometimes called Río Blanco) drainage basin - the basin draining the SE to SW sector of the volcano and surrounding terrain - was affected to varying degrees (Fig. 1). Within days of the heaviest tephra fall, the coastal town of Chaitén, $10 \mathrm{~km}$ south of the volcano at the mouth of Chaitén River, was inundated by $1-3 \mathrm{~m}$ of volcanic sediment flushed from the ash-mantled slopes of the drainage basin (Lara 2009).

In this paper, we show that (1) rapid remobilization of a large volume of volcanic ash was achieved in the Chaitén River drainage basin by only a modest amount of rainfall during the first pulse of a major Pacific storm; (2) downstream delivery of volcanic sediment caused rapid and profound geomorphic changes in the lower reaches of the river; (3) significant damage to a downstream community was accomplished by a complex, multi-peaked, sediment-water flow that began as a lahar and was followed closely by a prolonged muddy flood; and (4) some factors deemed responsible for profound hydrologic and sedimentation responses in volcanically disturbed basins elsewhere were not operative at Chaitén.

\section{Physiography and regional climate}

Chaitén volcano is situated near $43^{\circ} \mathrm{S}$ latitude about $10 \mathrm{~km}$ inland from the Gulf of Corcovado (Fig. 1). It consists of a rhyolite dome complex contained within a $3-\mathrm{km}$-diameter caldera. The caldera is surrounded by rugged mountain topography. The Chaitén River drains the caldera itself and steep glaciated bedrock terrain, densely covered with nearly impenetrable temperate rain forest vegetation. Ridges defining the drainage basin rise to about $1,000 \mathrm{~m}$ altitude; valleyfloor altitudes range from $0-400 \mathrm{~m}$. Valley side and head slopes average $35^{\circ}-45^{\circ}$ (ridge to valley), with some slope segments $50^{\circ}-70^{\circ}$. Bedrock geology is principally granodiorite and greenschist (SERNAGEOMIN 2002), and soils mantling the steep, glacially scoured, bedrock hillslopes appear to be thin $(<2 \mathrm{~m})$, mostly organic, and highly permeable. Patches of exposed bedrock are relatively small (primarily landslide scars). Steep sloping terrain comprises $83 \%$ of the basin area; volcaniclastic valley-fill deposits comprise $13 \%$. One tributary of the Chaitén River, informally named Caldera Creek (Fig. 1), drains the caldera through a narrow breach in the south rim. The bulk of the upper basin has a SE-NW orientation and is drained by the principal tributary, informally named East Fork (Fig. 1). The main-stem Chaitén River has a north-south orientation below the East Fork-Caldera Creek confluence. Average gradients of East Fork and Caldera Creek are 0.039 and 0.12, respectively; the main stem channel gradient averages 0.012 . Total catchment area is $77 \mathrm{~km}^{2}$.

Rainfall arrives in northern Patagonia $\left(40^{\circ}-48^{\circ} \mathrm{S}\right.$ latitude) mainly from strong, moisture-laden air flow from the southern Pacific Ocean. Maximum rainfall to the southern Andes occurs along seasonal storm tracks (Garreaud 2009) and is 
Fig. 1 Locations of Chaitén lava dome (red triangle); Chaitén caldera (black outlined polygon around red triangle in lower map); Chaitén town (red dot on lower map), $10 \mathrm{~km} \mathrm{SW}$ of the volcano at the mouth of Chaitén River; the informally named Chaitén River tributaries, Caldera Creek, and East Fork; and regional rain gauges (yellow dots on upper map). Tephra isopachs (in red) across Chaitén River drainage basin (outlined in black) are for minimum total tephra accumulation from the 20082009 eruption and are based on a total-thickness isopach map of Alfano et al. (2011), supplemented with unpublished field measurements within the basin. Mapped tephra thicknesses are minimum values owing to considerable surface erosion that occurred prior to field measurements. Small dots on lower map (one white, two black) are tephra photo or sample locations referred to in text and in Fig. 2 caption

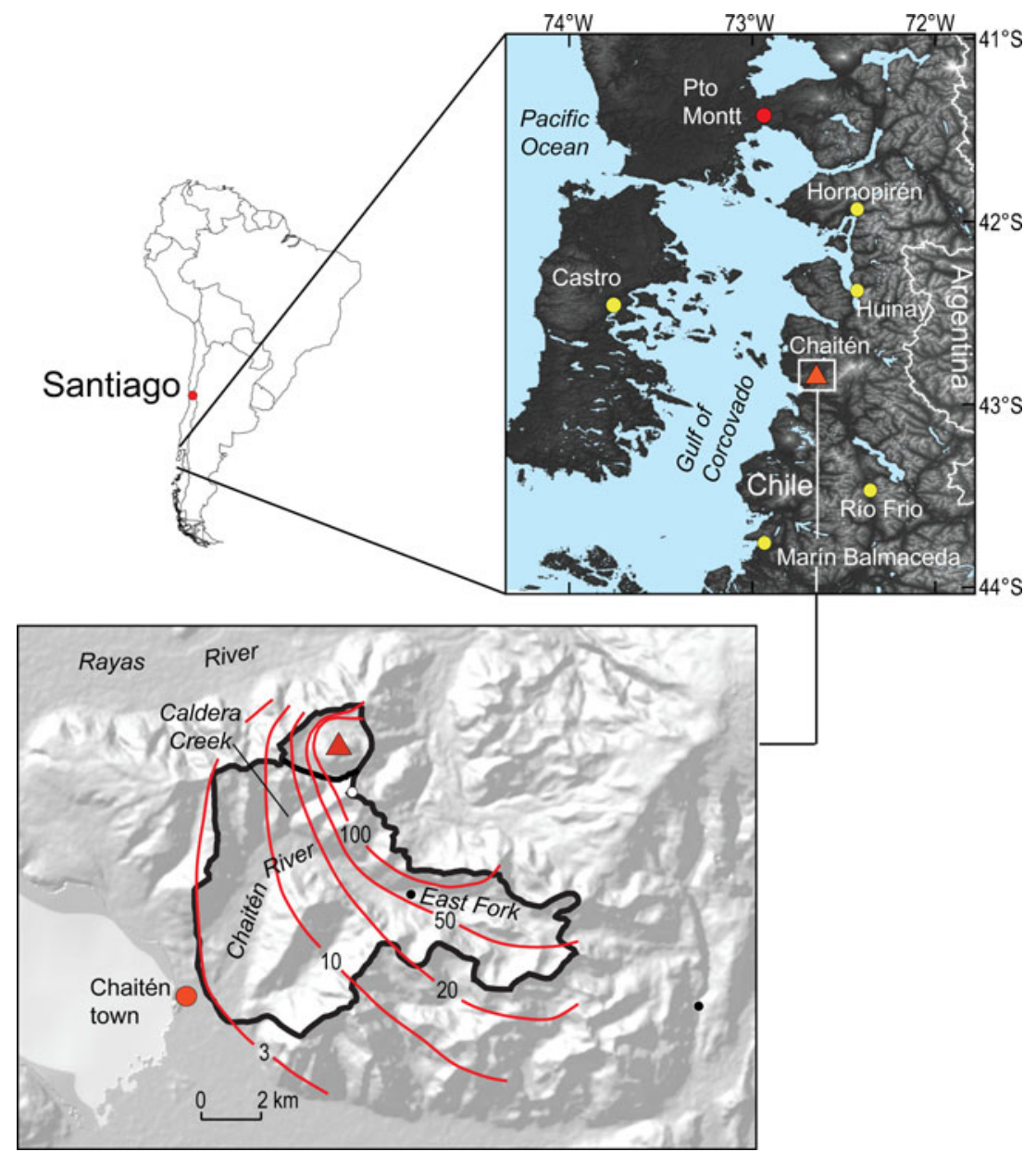

delivered mainly by westerly (NW to SW) winds (Smith and Evans 2007). Frontal storms traverse low-relief offshore islands and locally a narrow coastal plain (Fig. 1) before air masses encounter a series of steep mountain ridges 1$2 \mathrm{~km}$ in altitude. Orographic precipitation increases with altitude as air masses ascend the western Andean slope; annual precipitation exceeds $6,000 \mathrm{~mm}$ just west of the continental divide at $45^{\circ} \mathrm{S}$ - two to three times the annual totals along the coast (Garreaud 2009; Dirección General de Aguas, 2006-2008, unpublished data). Recent annual precipitation (2004-2009) in the broad region surrounding Chaitén volcano has varied from about 2,500 to 7,000 mm (Dirección General de Aguas, 2006-2008, unpublished data; Fundación Huinay 2008).

\section{The explosive phase of the 2008-2009 eruption and tephra fall}

Following hundreds of years of quiescence (Lara et al. 2013), Chaitén volcano began erupting high-silica rhyolite tephra on the evening of May 1, 2008 (local time, UTC -4). Vigorous explosive activity commenced in the early morning hours of May 2, 2008 (Castro and Dingwell 2009; Lara 2009). Intermittent large explosions from May 2-8 generated many-kilometers-high eruption columns, with the plume from the climactic explosion on May 6 rising to 20+ km (Carn et al. 2009; Durant et al. 2012). Tephra fall initially blanketed the region ESE of the volcano from May 3-5 (Alfano et al. 2011; Osores et al. 2013). A large eruption column drifting NE on May 6 produced the thickest and coarsest tephra layer, one rich in lithic rhyolite particles ( $\beta$-layer of Alfano et al. 2011, 2012). Another substantial explosion occurred on May 8 (Lara 2009; Durant et al. 2012). Tephra from that explosion drifted mainly to the east, although close to the volcano it may also have drifted NE to SE (e.g., Osores et al. 2013). Explosive activity waned after May 8, and effusive activity began about May 12 (Carn et al. 2009; Pallister et al. 2013a), but minor quantities of fine ash continued to accumulate in the basin through early 2009 (Alfano et al. 2011). Escalating explosive activity prompted a full evacuation of the town of Chaitén (population $\sim 4,600$ ) by May 6 .

Eruption plumes deposited a complex succession of tephra layers over a broad area, principally northeast to southeast 
of the volcano (Alfano et al. 2011). Almost all of the Chaitén River basin received at least $3 \mathrm{~cm}$ of tephra, and parts of the upper basin received more than $1 \mathrm{~m}$ (Fig. 1). In the upper East Fork, the tephra mantle generally graded from fine lapilli and coarse ash at the base to much finer ash at the top (Fig. 2a). No samples from within the Chaitén River basin were analyzed for particle size, but a tephra sample collected about $5 \mathrm{~km}$ downwind of the upper East Fork drainage divide (Fig. 1) is composed mainly of fine to extremely fine ash, with the finest material $(>80 \%$ finer than $0.250 \mathrm{~mm}$ ) in the upper layers (J. Castro, Johannes Gutenberg Universität Mainz, 2012, written communication). Tephra componentry in the 1-mm, coarse ash fraction of this sample comprises about $85 \%$ white pumice, $10 \%$ gray microcrystalline rhyolite, and $5 \%$ obsidian. The lower Chaitén basin outside of the main tephra trajectories received only a few centimeters of ash, appearing fine to extremely fine in the field. Tephra fall in much of the upper Chaitén River basin caused only modest physical damage immediately, although the heaviest rain of tephra stripped foliage and limbs from trees within a kilometer of the vent, particularly east of the caldera (Fig. 2b; Swanson et al. 2013).

\section{Methods}

Rainfall data are available only from widely dispersed rain gauges in northern Patagonia. Consequently, rainfall to the Chaitén River drainage basin had to be estimated from records of relatively distant rain gauges (Fig. 1, Table 1). The gauge nearest the volcano is at Huinay ( $60 \mathrm{~km}$ NNE of Chaitén), situated on the shore of a narrow fjord oriented NNW and sandwiched between very steep mountain ridges rising to about $1,000 \mathrm{~m}$. The Río Frio gauge ( $78 \mathrm{~km} \mathrm{SSE}$ of Chaitén) is located in a north-south inter-Andean valley $60 \mathrm{~km}$ inland from the coast in the rain shadow of a mountain ridge 1,200-1,500 $\mathrm{m}$ in altitude. The next two closest gauges along the mountain front are Hornopirén $(105 \mathrm{~km} \mathrm{~N})$ at the northern head of a fjord, and Marín Balmaceda $(107 \mathrm{~km} \mathrm{SSW})$ on the coast. A rain gauge at Castro on low-lying Chiloé Island ( 100 km WNW) captures less rain than other gauges during Pacific storms, but the timing of winter frontal storms at that location should be about the same as at Chaitén. All of the gauges provide daily rainfall totals; the Huinay gauge also provides 30 -min rainfall intensities. May 2008 rainfall data from the four mainland gauges and from Chiloé Island are summarized in Table 1.

A rain gauge at the Chaiten airport near the mouth of Chaiten River was abandoned during the evacuation of Chaitén town and clogged with ash; no data were recovered. For the 2 years before the eruption, the Huinay and Chaitén rain gauges operated simultaneously. The average daily rainfall at Huinay was $48 \%$ greater than at Chaitén in
2006 and $23 \%$ greater in 2007, and the 2006 and 2007 daily averages for May were $95 \%$ and $26 \%$ greater at Huinay. The Chaitén and Río Frio gauges recorded similar average daily totals from 2004 to 2007, differing by less than $1 \mathrm{~mm}$ in 3 of those 4 years (Dirección General de Aguas, 2006-2008, unpublished data).

Because rain gauges are sparse and widely spread, we assume that averaging storm rainfall from the Huinay and Río Frio gauges best approximates rainfall received by the Chaitén River basin as a whole in May 2008 (Table 1). We further assume that winter frontal storms are typically widespread and deliver rainfall broadly across the region, in contrast to austral summer storms that typically deliver rainfall across more isolated and focused areas (Garreaud 2009). For physiographic reasons (equally high surrounding mountain ridges), the Huinay gauge probably receives orographic rainfall that is somewhat equivalent to what is received in the upper Chaitén River drainage basin. The Río Frio gauge collects rainfall amounts similar to those at the mouth of the Chaitén River.

Repeat vertical and oblique, time-stamped imagery from various high-altitude remote-sensing platforms (ASTER, Advanced Land Imager, and Formosat-all from NASA Earth Observatory, http://earthobservatory.nasa.gov) and photographs taken by SERNAGEOMIN geologists (primarily co-author HM) from low-altitude helicopter flights immediately following the eruption were used to constrain the timing, extent, and rate of channel sedimentation. Objects of known dimension (fence posts, bridge piers, bridge railings, etc.) were used to scale amounts of channel aggradation from pre- and post-inundation photos. We assume that fill estimates scaled from photographs have errors of about $\pm 0.5 \mathrm{~m}$.

Field work involved examining and collecting samples of the sedimentary fill in the Chaitén River valley in JanuaryFebruary 2010 and in January and March 2011. Because naturally incised bank sections were only about $3.5 \mathrm{~m}$ high in 2010, and the channel fill is twice that amount, we excavated a 4.6-m-deep trench (limit of the excavator) in the abandoned river channel next to the airport in Chaitén town. By March 2011, river incision had revealed about $5 \mathrm{~m}$ of the 2008 fill, but an estimated $2 \mathrm{~m}$ of fill remained unexposed.

\section{Rainfall and sedimentation following tephra deposition}

Storm characteristics and timing

A modest amount of rain (about $34 \mathrm{~mm}$ ) fell in the Chaitén River basin during the early part of the eruption's explosive phase. That rainfall was concentrated in two pulses on May 4 and May 5-6 (timing based on Huinay and Castro rain gauges; Table 1, Fig. 3a, b), with rain ending prior to the major explosion on May 6. Thirty-minute intensities at 


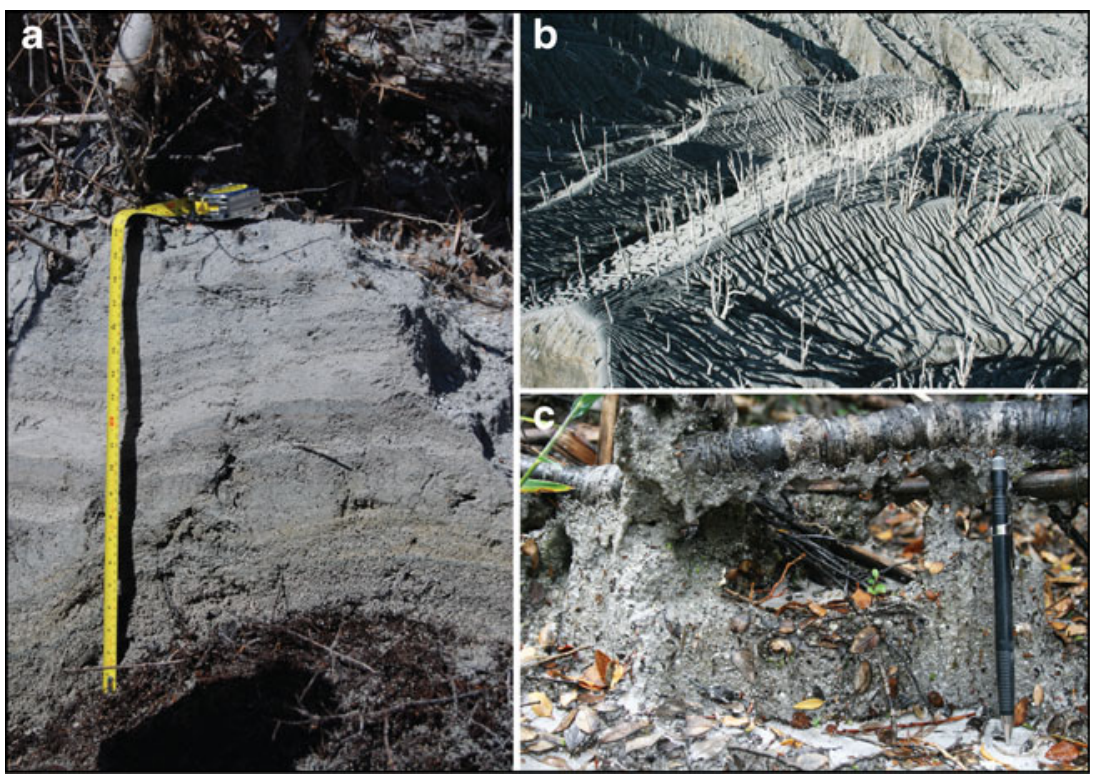

Fig. 2 Tephra and hillslope erosion in Chaitén River basin. a A 53$\mathrm{cm}$-thick tephra section located along the East Fork channel about $5 \mathrm{~km}$ upstream of the confluence with Caldera Creek (black dot above "East" in lower map of Fig. 1). Lower half of section composed of mostly medium gray, medium to coarse ash (field evaluation); upper half of section composed mostly of light gray, fine to extremely fine ash. USGS photograph by JJM, January 22,2010 . b Aerial oblique view (to SE) of thick ( $1 \mathrm{~m})$ tephra mantle along the divide between Chaitén and Rayas River basins about half a kilometer southeast of the caldera rim. Photograph shows deep gullies cut into the tephra mantle and devastation of forest vegetation in that area. USGS photograph by TCP, January 21, 2010. c Elongate pedestal (miniature wall) of tephra preserved beneath a fallen branch that had been resting on the fresh 2008 tephra surface about $4 \mathrm{~km}$ east of the Chaitén basin drainage divide (black dot near right edge of lower map in Fig. 1). This is one of many examples of ash pedestals preserved in the 2008 tephra, formed by erosion of the surrounding, unprotected tephra surface. Pencil is $15 \mathrm{~cm}$ long. USGS photograph by TCP, February 2, 2010
Huinay were as much as $8 \mathrm{~mm} / \mathrm{h}$. Nearly 5.5 days with $<2 \mathrm{~mm}$ total precipitation followed (0200 hours on May 6 to midday May 11) during the waning part of the explosive phase of the eruption (Table 1, Fig. 3a, b).

Beginning around midday on May 11, the advancing front of a sustained frontal storm delivered a relatively minor pulse of rain (pulse 1) to the Chaitén River basin (Fig. 3a, b). Minor rainfall continued until the early hours of May 12. The estimated averaged rainfall to the basin over these 2 days was only about $20 \mathrm{~mm}$ (Table 1, Fig. 3a), and 30 -min intensities at Huinay never exceeded $3 \mathrm{~mm} / \mathrm{h}$ until late in the evening of May 12 (Fig. 3b). Heavier rainfall began on May 13 and delivered $600-900 \mathrm{~mm}$ of rain over the next 12 days (Table 1, Fig. 3).

\section{Sedimentation response in Chaitén River}

The rainfall on May 4-6 appeared to have little hydrologic or geomorphic effect on the Chaitén River, despite widespread tephra fall across the Chaitén River drainage basin on May 3-5 (Alfano et al. 2011; Osores et al. 2013). No observations of unusual river behavior were reported by police or residents in Chaitén town before full evacuation was completed on May 6, although the river was highly turbid and floating pumice was observed from a low-altitude overflight on May 7 (SERNAGEOMIN 2008a). Tephra stratigraphy along the East Fork channel (Fig. 2a) shows that $\sim 30 \mathrm{~cm}$ of relatively coarse tephra (fine lapilli to medium ash) fell at this location before finer ash started to accumulate. High-concentration flood deposits on a low terrace along this channel overlie all of the coarse layers of the tephra sequence and some of the fine, indicating that the flood occurred after fine ash had begun mantling the hillslopes.

In contrast to the insignificant runoff and sediment production during the rain on May 4-6, the smaller total and peak-intensity rainfall on May 11-12 (pulse 1, Fig. 3b) produced an extraordinary sedimentation response in the Chaitén River basin (Figs. 3c and 4a, b). That response resulted from erosion and mobilization of fresh tephra by overland sheetflow and concentrated flow in rills and gullies (Fig. 2b) from basin-wide rainfall runoff. Very little shallow landsliding of the tephra mantle was observed during helicopter overflights, although much of the basin's ash mantle was shielded from view by dense forest vegetation, and post-event satellite imagery showed (from very limited channel-margin erosion) that only minimal flow came from the caldera. Observations in Chaitén town by one of us (AA) at midday on May 11 confirmed that the river was confined to its channel, not flowing at an unusually high stage, and not extraordinarily sediment laden. Slightly more than $24 \mathrm{~h}$ later, by midafternoon on May 12, the 70-m-wide and leveed river channel adjacent to town had aggraded by nearly 
Table 1 Daily rainfall (in mm) for rain gauges nearest to Chaitén River drainage basin (Dirección General de Aguas, 2006-2008, unpublished data; Fundación Huinay 2008)

\begin{tabular}{|c|c|c|c|c|c|c|}
\hline $\begin{array}{l}\text { DAY } \\
\text { May } 2008\end{array}$ & $\begin{array}{l}\text { Castro } \\
42^{\circ} 27^{\prime} 00^{\prime \prime} \mathrm{S} \\
73^{\circ} 46^{\prime} 00^{\prime \prime} \mathrm{W} \\
50 \mathrm{~m} \text { asl }\end{array}$ & $\begin{array}{l}\text { Hornopirén } \\
41^{\circ} 56^{\prime} 00^{\prime \prime} \mathrm{S} \\
72^{\circ} 26^{\prime} 00^{\prime \prime} \mathrm{W} \\
25 \mathrm{~m} \text { asl }\end{array}$ & $\begin{array}{l}\text { Huinay } \\
42^{\circ} 22^{\prime} 44.6^{\prime \prime} \mathrm{S} \\
72^{\circ} 24^{\prime} 50.6^{\prime \prime} \mathrm{W} \\
15 \mathrm{~m} \text { asl }\end{array}$ & $\begin{array}{l}\text { Río Frio } \\
43^{\circ} 28^{\prime} 00^{\prime \prime} \mathrm{S} \\
72^{\circ} 21^{\prime} 00^{\prime \prime} \mathrm{W} \\
215 \mathrm{~m} \text { asl }\end{array}$ & $\begin{array}{l}\text { Marín Balmaceda } \\
43^{\circ} 46^{\prime} 00^{\prime \prime} \mathrm{S} \\
72^{\circ} 57^{\prime} 00^{\prime \prime} \mathrm{W} \\
10 \mathrm{~m} \text { asl }\end{array}$ & $\begin{array}{l}\text { Mean: Huinay + Río Frio } \\
\text { (Surrogate for Río } \\
\text { Chaitén watershed) }\end{array}$ \\
\hline 1 & 0 & 0 & 0.0 & 0 & 0.0 & 0.0 \\
\hline 2 & 0 & 0 & 0.5 & 0 & 0.0 & 0.3 \\
\hline 3 & 0 & 3.5 & 0.0 & 12 & 22.0 & 6.0 \\
\hline 4 & 5.4 & 14 & 13.2 & 0 & 2.6 & 6.6 \\
\hline 5 & 3.3 & 9 & 15.2 & 22 & 0.0 & 18.6 \\
\hline 6 & 0.8 & 0 & 5.3 & 0 & 3.4 & 2.7 \\
\hline 7 & 0.7 & 0 & 0.3 & 0 & 15.8 & 0.2 \\
\hline 8 & 0.3 & 0 & 0.3 & 0 & 2.6 & 0.2 \\
\hline 9 & No data & 0 & 0.0 & 3 & 3.2 & 1.5 \\
\hline 10 & No data & 0 & 0.0 & 0 & 8.0 & 0.0 \\
\hline 11 & 1.3 & 0 & 9.9 & 0 & 1.3 & 5.0 \\
\hline 12 & 18.3 & 20 & 14.2 & 14.5 & 22.9 & 14.4 \\
\hline 13 & 10 & 55 & 42.4 & 77.5 & 37.6 & 60.0 \\
\hline 14 & 55.3 & 30 & 185.2 & 40 & 62.8 & 112.6 \\
\hline 15 & 6.7 & 36 & 20.6 & 12 & 8.3 & 16.3 \\
\hline 16 & 40.4 & 98 & 192.8 & 47 & 13.2 & 119.6 \\
\hline 17 & 34.7 & 20 & 123.4 & 47 & 21.5 & 85.2 \\
\hline 18 & 22.2 & 60.5 & 58.4 & 0 & 13.4 & 29.2 \\
\hline 19 & 0.3 & 25.5 & 0.5 & 25.5 & 2.7 & 13.0 \\
\hline 20 & 35.4 & 50 & 96.5 & 10.5 & 12.4 & 53.5 \\
\hline 21 & 14.3 & 8.5 & 27.2 & 30.7 & 8.3 & 29.0 \\
\hline 22 & 34 & 44.5 & 66.6 & 32.2 & 6.1 & 49.4 \\
\hline 23 & 14.5 & 1.5 & 8.9 & 0 & 15.7 & 4.5 \\
\hline 24 & 0 & 29.5 & 4.3 & 0 & 13.0 & 2.2 \\
\hline 25 & 0.2 & 0 & 47.0 & 0 & 0.0 & 23.5 \\
\hline 26 & 0 & 0 & 0.0 & 0 & 0.0 & 0.0 \\
\hline 27 & 0 & 0 & 0.0 & 0 & 0.0 & 0.0 \\
\hline 28 & 0 & 0 & 0.0 & 0 & 0.0 & 0.0 \\
\hline 29 & 0 & 0 & 0.0 & 0 & 0.0 & 0.0 \\
\hline 30 & 0 & 0 & 0.3 & 0 & 0.0 & 0.2 \\
\hline 31 & 0 & 0 & 0.0 & 0 & 0.0 & 0.0 \\
\hline
\end{tabular}

$5 \mathrm{~m}$ (Fig. 3c), and a delta had begun growing at the original river mouth. Flow had breached the town's protection levee in several locations and deposited overbank sediment along a 200-m-wide swath on either side of the channel (Fig. 4c, d).

Heavier rainfall (about $120 \mathrm{~mm}$ ) from late May 12 through the afternoon of May 14 (pulse 2 and the first part of pulse 3, Fig. 3b) caused more aggradation, and by midday on May 14, the river bed was approximately $7 \mathrm{~m}$ above its original level (Table 1, Fig. 3c). Sediment loads remained high for at least another week during the storm, and the river bed fluctuated about the $7 \mathrm{~m}$ level. This additional $2+\mathrm{m}$ of aggradation triggered channel avulsions through the middle of the town (Fig. 5a, b), and widespread flooding and sediment deposition occurred throughout the town and surrounding low-lying areas, including inundation of the airport. Channel avulsions occurred as late as May 20, when the highway bridge over the Chaitén River became a dam and diverted most of the river flow through streets in the north part of the town (SERNAGEOMIN 2008b). One avulsion downstream of the bridge eventually became the permanent new channel for the lower part of the river (Fig. 5b). Channel incision (degradation) of the fresh fill began in late May (Fig. 3c), and by March 2011, the channel bed had returned to within about $2 \mathrm{~m}$ 

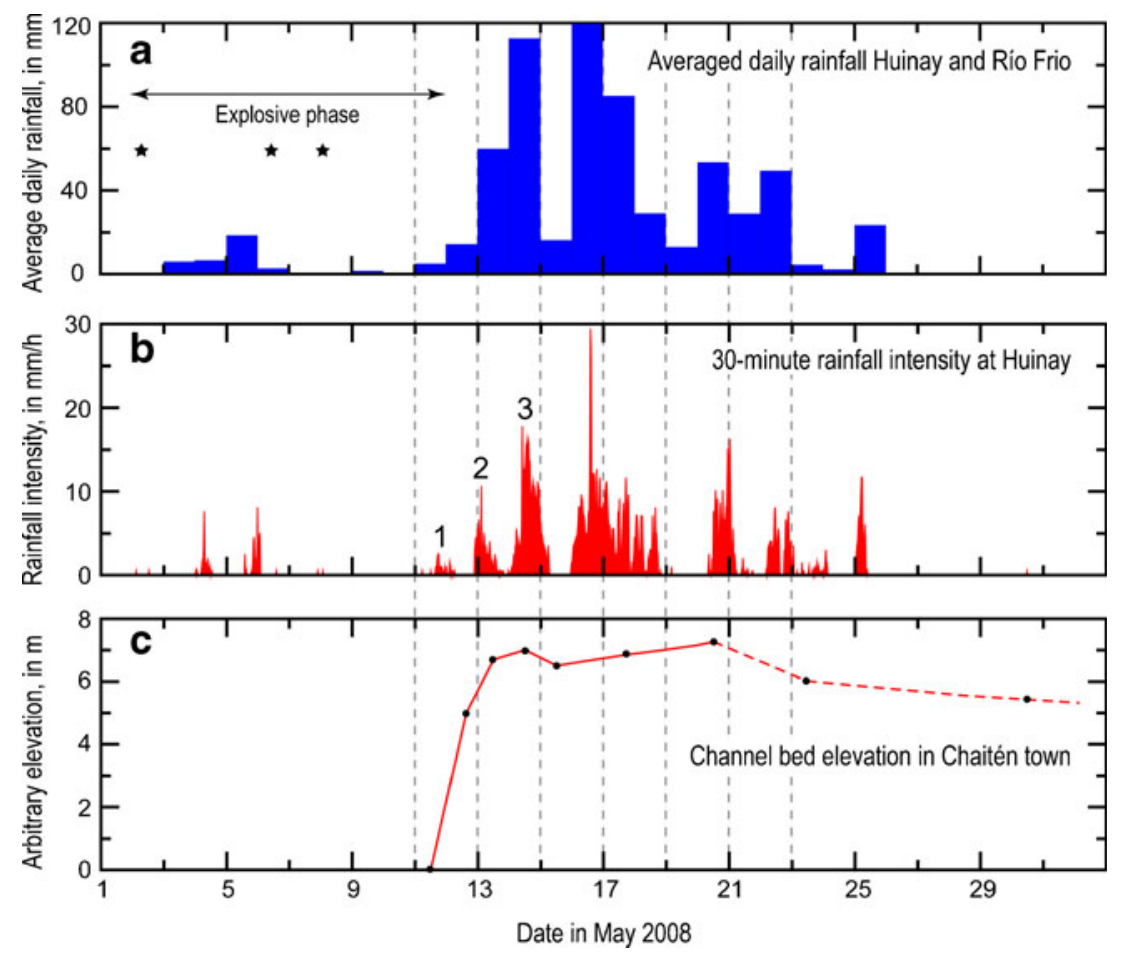

Fig. 3 Timelines of explosive eruptive activity, regional rainfall daily totals and 30-min intensities, and changes in Chaitén River channel bed elevation in May 2008. a Average of daily rainfall totals from Huinay and Río Frio gauges (Table 1, Fig. 1). Arrow shows duration of principal explosive phase of the eruption (Pallister et al. 2013a); black stars mark times of major explosive activity (Carn et al. 2009; Lara 2009). b Thirty-minute rainfall intensity (in millimeters per hour) recorded at Huinay rain gauge (Fundación Huinay 2008). Data are plotted in consecutive 30 -min increments. Numbers identify rainfall

of its pre-eruption bed level-nearly completing an aggradation-degradation cycle.

The Chaitén River was not gauged, and peak-flow discharge during aggradation was not measured. Peak-flow stage just before the permanent avulsion occurred (obtained from high-water marks along the abandoned channel) was about $1.5 \mathrm{~m}$ above the aggraded channel bed near the airport, where channel width was about $100 \mathrm{~m}$. If peakflow velocity had been $2-3 \mathrm{~m} / \mathrm{s}$, a reasonable range for high-concentration floods about $1 \mathrm{~m}$ deep in similar channels (Pierson and Scott 1985), then peak discharge immediately prior to channel avulsion can be estimated to have been in the range of $350-550 \mathrm{~m}^{3} / \mathrm{s}$. For comparison, summer low flow in 2010 at this location was $5-10 \mathrm{~m}^{3} / \mathrm{s}$ (A. Iroumé, Universidad Austral de Chile, 2010, written communication).

\section{Deposit sedimentology and stratigraphy}

Sediment particles in the Chaitén River valley depositional sequence are composed almost exclusively of two grain types: (a) fresh, light to medium gray, slightly vesicular to nonvesicular, largely aphyric, lithic rhyolite pulses 1, 2, and 3 associated with the lahar-flood event described in text. c Timing and magnitude of channel aggradation in Chaitén town, scaled from photographs (by HM) from low-elevation helicopter overflights over the town. Elevation datum of channel bed is the approximate pre-eruption bed level. Dated ticks on $x$-axis mark beginning of indicated day (i.e., "13" marks beginning of May 13th at 0000 hours). Estimated error in bed elevations is assumed to be $\pm 0.5 \mathrm{~m}$; dashed line indicates slightly greater uncertainty

(grain densities of 1.76 to $2.49 \mathrm{~g} / \mathrm{cm}^{3}$ on sampled fine lapilli) and (b) fresh, white, highly to poorly vesicular pumice, ranging in dry density from 0.4 to $1.3 \mathrm{~g} / \mathrm{cm}^{3}$ (Alfano et al. 2012). Wet densities of fine pumice lapilli measured from the river deposits (i.e., lapilli allowed to soak up water during density measurement) were greater- 1.3 to $1.6 \mathrm{~g} / \mathrm{cm}^{3}$ - due to the large percentage of open porosity in the Chaitén pumice (Alfano et al. 2012). Gray lithic rhyolite grains dominate the composition of the river sediment relative to pumice, where pumice is visually estimated to range from 5 to 40 volume percent. Only trace amounts of accidental lithic fragments (granodiorite and greenschist country rock and weathered volcaniclastic particles) were present in the river sediment. This componentry indicates that the fresh tephra mantling basin slopes was the chief sediment source.

The volcaniclastic sediment emplaced on May 11-14 in the lower Chaitén River valley consists of three basic lithofacies (Fig. 6, Table 2). All three lithofacies in the examined deposits are dominated by sand, and the coarsest gravel clasts (pumice) are only $2-3 \mathrm{~cm}$ in diameter and rare. 


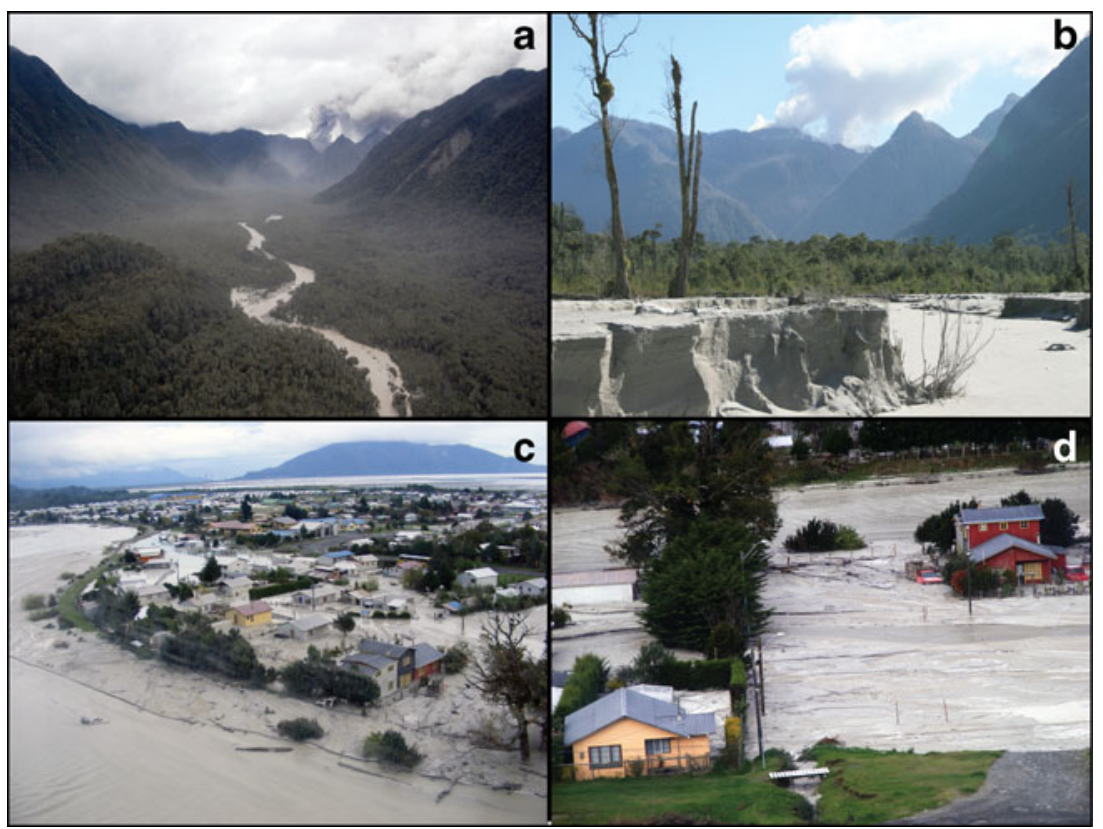

Fig. 4 Flood sedimentation along the Chaitén River. a Aggradational channel fill along Chaitén River channel 1-2 km upstream of Chaitén town. Fume and ash from lava dome visible at head of valley. SERNAGEOMIN photograph by J. Muñoz, May 24, 2008. b Top surface of aggradational channel-fill section deposited in May 2008, about $1 \mathrm{~km}$ upstream of Chaitén town. Right side of photo shows an abandoned shallow channel that was incised into the fill at start of downcutting. Active channel is farther to the right. USGS photograph by TCP, March 6, 2011. c Deposition and flooding along lower Chaitén
River valley. Note shallow flow in the mostly filled channel (lower left of photo) and overbank inundation along narrow swath near the channel; view looking downstream and across town to bay. SERNAGEOMIN photograph by HM, May 12, 2008. d View of Chaitén River mid-afternoon on May 12. About $5 \mathrm{~m}$ of aggradation had already occurred in channel (in background); overbank flooding and deposition had begun, shown in foreground. SERNAGEOMIN photograph by HM, May 12, 2008. Flow direction left to right

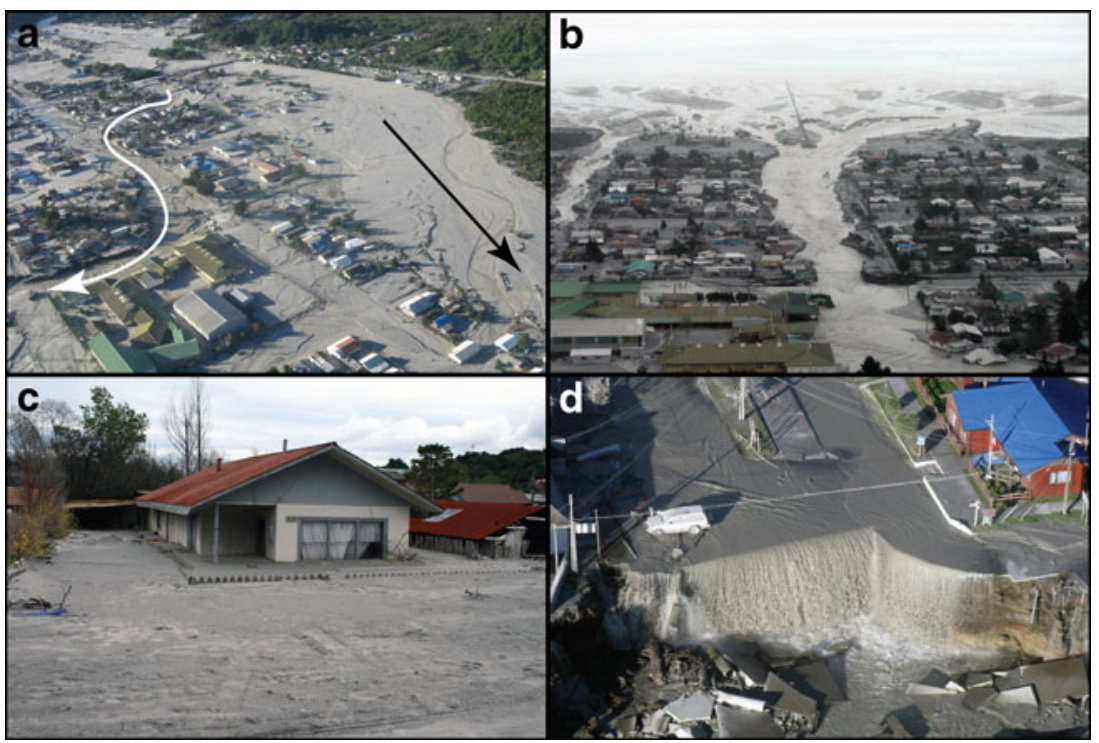

Fig. 5 Damage to Chaitén town by flooding and sediment deposition, May 2008: a Deposition in Chaitén town, looking upstream. Note filled and abandoned channel on right (black arrow) and newly avulsed channel following streets on left (white arrow). SERNAGEOMIN photograph by HM, May 26, 2008. b New channel cutting through town and widening, following avulsion and abandonment of the lower $3 \mathrm{~km}$ of channel. Flow direction away from camera toward bay.
SERNAGEOMIN photograph by HM, May 23, 2008. $\mathbf{c}$ House in north part of town inundated by flood deposits. USGS photograph by TCP, January 19, 2010. d Knickpoint in new river channel near bay shore, prior to its upstream retreat. Sections of collapsed road pavement are visible in foreground. SERNAGEOMIN photograph by HM, May 26, 2008 

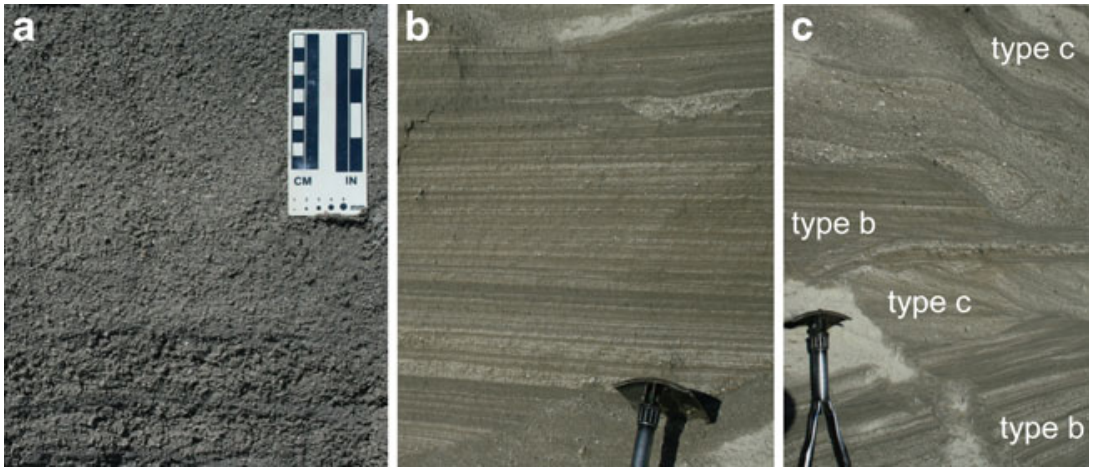

Fig. 6 Characteristic lithofacies in 2008 aggradational channel fill in Chaitén River valley. a Type A deposit. This was deposited by a hyperconcentrated-flow lahar that was close to the transition to debris flow. Most of deposit in frame is massive, but note faint horizontal bedding developed in lower part. b Distinctly horizontally bedded (plane-bed) type B deposit. This was deposited by dilute

- Type A lithofacies: Massive to weakly horizontally stratified, pumice-rich, medium to very coarse sand and fine gravel, supported in a silty sand matrix, are found in the lower part of the channel-fill section. This lithofacies, which locally is a fine-grained diamict, is ungraded to normally graded and very poorly sorted. It contains fresh rhyolitic gravel up to about $1 \mathrm{~cm}$ in diameter, and its outcrops have firm to very firm consistence. Sorting values (standard deviation of distribution in phi units; Folk 1980) range from $1.6 \varphi$ to $2.2 \varphi$, and fines contents (silt- and clay-size particles) range from 10 to 15 weight percent. Size distributions are strongly fine skewed. Type A deposits grade into zones having less muddy matrix and more pronounced horizontal stratification (type B lithofacies). Locally type A deposits are bounded by sharp contacts.

- Type B lithofacies: Horizontally stratified, pumice-rich, medium sand to fine gravel with moderately to sharply defined contacts between beds are found in the upper part of the channel-fill section. Beds are $0.3-3 \mathrm{~cm}$ thick and parallel, extend laterally for meters, and locally display low-angle cross-bedding and scour-and-fill structures. Sand beds commonly contain scattered outsized gravel clasts. This lithofacies is characteristically poorly sorted (sorting $1.3 \varphi$ to $1.8 \varphi$ ), with fines contents of 8 to 12 weight percent and size distributions ranging from near-symmetrical to strongly fine skewed. Outcrops exhibit friable to slightly firm consistence. Type B deposits are locally separated from type C lithofacies deposits by erosional unconformities, but generally the contact is gradational.

- Type C lithofacies: This lithofacies consists of both channel and overbank depositional facies. The channel facies is composed largely of cross-bedded, pumice-rich, medium to coarse sand and fine gravel, with some zones hyperconcentrated flow or highly concentrated (muddy) streamflow. Trenching-tool blade is $15 \mathrm{~cm}$ wide. c High-angle cross-bedded type $\mathrm{C}$ deposit alternating with zones of type $\mathrm{B}$ deposit. Type $\mathrm{C}$ lithofacies was deposited by a more dilute muddy streamflow phase of the flood. USGS photographs by TCP

of horizontal bedding; sharp contacts separate individual beds. Beds are $3-10 \mathrm{~cm}$ thick, ungraded, and display low- to high-angle cross-stratification and scour-and-fill structures. Pumice gravel to several centimeters diameter is commonly segregated in lenses or beds having openwork structure. Size distributions range from coarse skewed to near-symmetrical. The overbank facies, deposited where flow was poorly confined and shallow, is much finer grained, occurring as thinly bedded to finely laminated medium sand to silt; bed forms include horizontal laminae and small-scale ripple cross-bedding. Overall, this lithofacies is characteristically poorly sorted but is locally moderately to well sorted (sorting values $0.4 \varphi$ to $1.9 \varphi$ ), with fines contents of 3 to 5 weight percent in channel-facies samples and 20 to 80 weight percent in the much finer overbank-facies samples. Outcrops exhibit a loose to friable consistence, although some well-packed silts are firm. The upper surface of the Chaitén channel-fill deposit was locally reworked by fluvial action following deposition, resulting in redeposition of well-sorted, extensively cross-bedded medium to coarse sand.

Interpretation of deposits and the lahar-flood event

Four stratigraphic sections from 2010 and 2011 exposures of the channel-fill sediment in the Chaitén River about $10 \mathrm{~km}$ downstream of the volcano reveal the occurrence of lithofacies types in the vertical sequence (Fig. 7). Type A deposits are characteristic of hyperconcentrated flow that is transitional to dilute debris flow, based on particle-size distributions and sedimentary structures (Pierson and Scott 1985 Smith 1986, Scott 1988; Smith and Lowe 1991; Pierson 2005). The type A deposit at the base of the Bluff Section has a hard consistence and may have been emplaced 


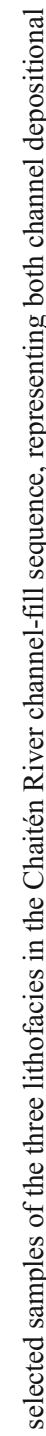

获

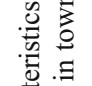

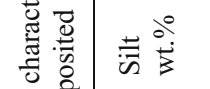

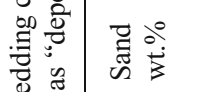

吾

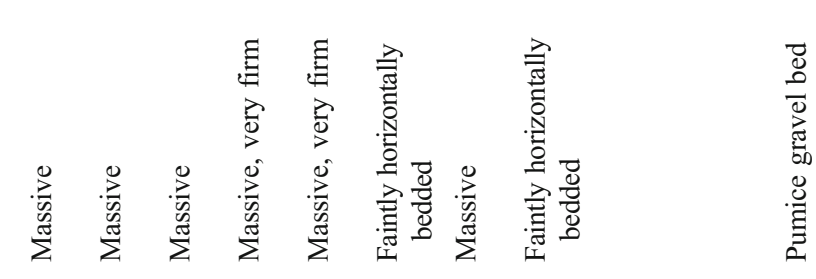

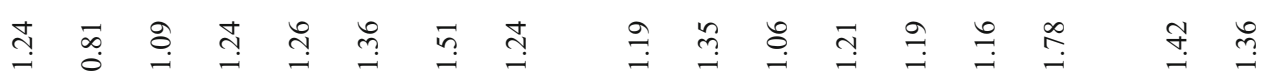

๗․

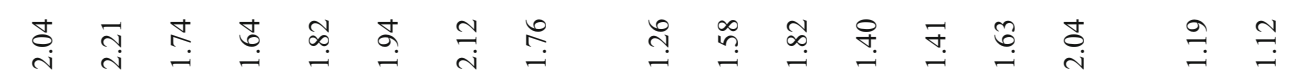

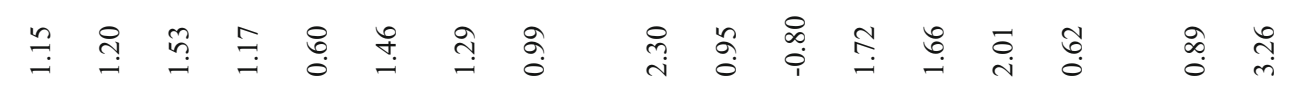

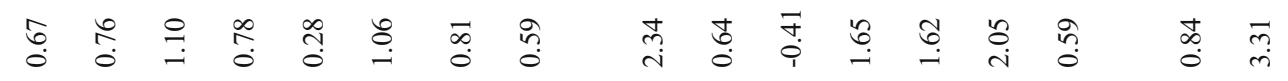

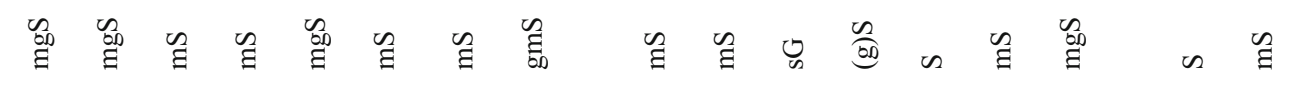

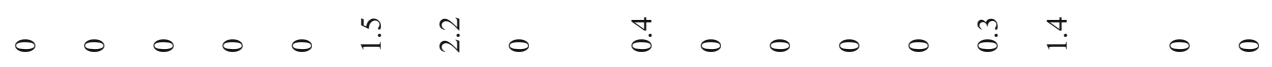

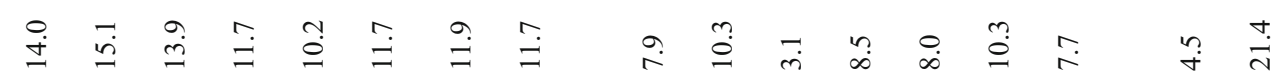

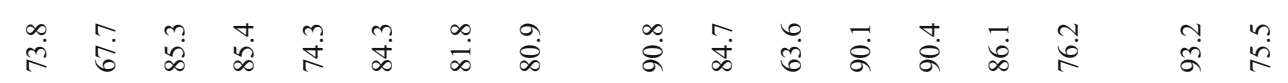

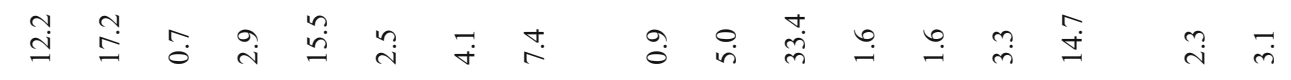

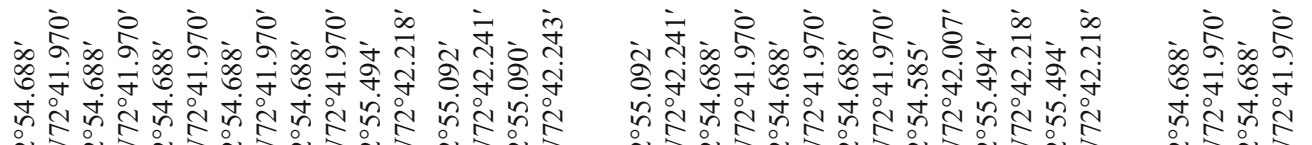

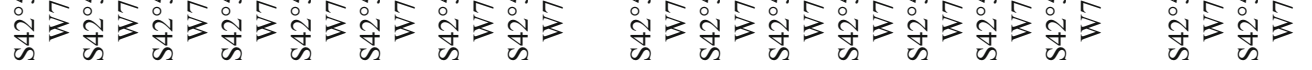

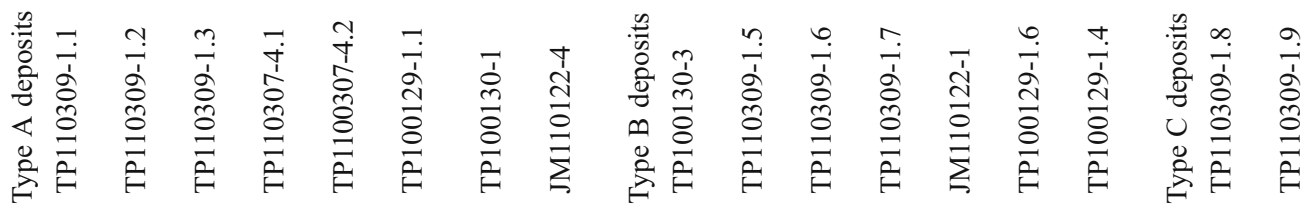




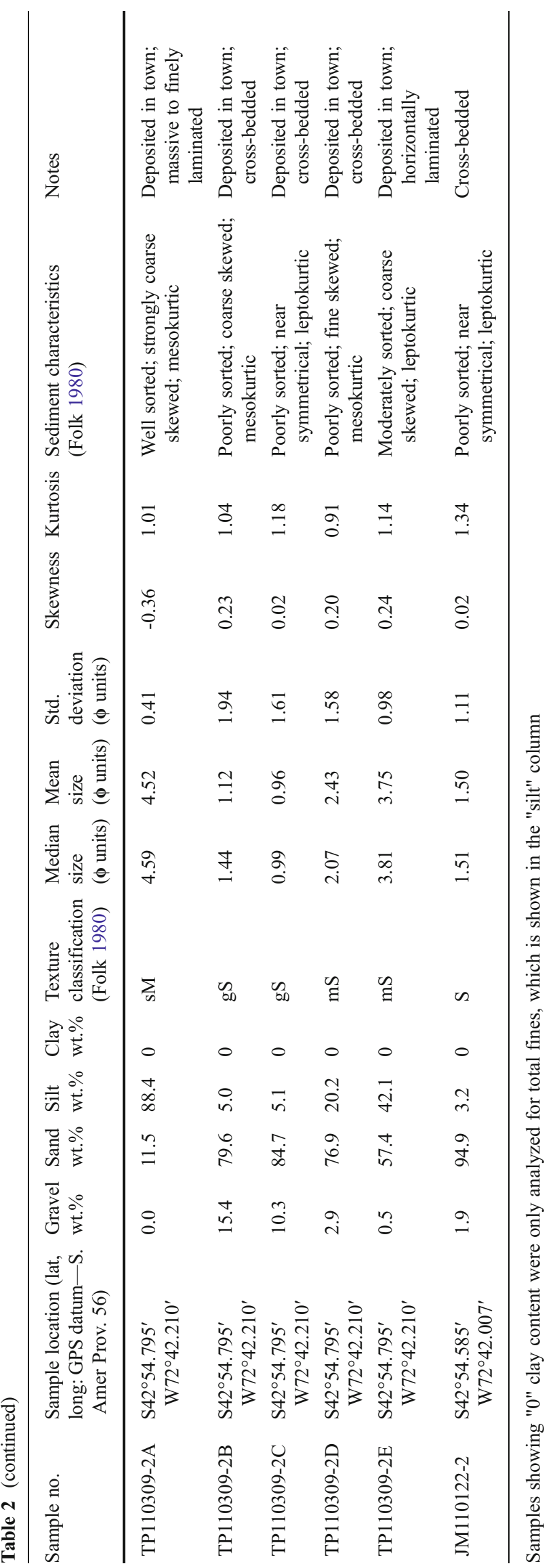

by fully formed debris flow. Type B deposits are characteristic of both dilute hyperconcentrated flow (Smith 1986; Smith and Lowe 1991; Pierson 2005) and muddy streamflow under upper-flow-regime (generally supercritical turbulent flow) conditions (Harms et al. 1963; Simons et al. 1965; McKee et al. 1967). The high fines contents and poor sorting of the deposits indicate that emplacement occurred by a flow close to the transition between hyperconcentrated flow and muddy streamflow. Type C channel deposits exhibit gravel segregation, cross-cutting relations, and high-angle cross-bedding - characteristics of streamflow in braided channels under predominantly lowerflow-regime (generally subcritical turbulent flow) conditions (Simons et al. 1965; Williams and Rust 1969; Smith 1970). However, the relatively high silt and clay contents of some of these deposits suggest that the flood water carried a high suspended-sediment load. Type B deposits grading upward to type $\mathrm{C}$ deposits reflect a decrease in concentration, a waning in flood discharge, or both (McKee et al. 1967; Smith 1986). Fine-scale horizontal stratification in some overbank facies deposits probably reflects very shallow, largely unconfined, lower-regime flow from levee overtopping rather than upper-regime plane-bed conditions (Smith 1971).

Channel-fill stratigraphy, deposit sedimentology, rainfall records, and eyewitness observations show that rainfall totaling $\sim 20 \mathrm{~mm}$ (pulse 1; Table 1, Fig. 3b), from about midday on May 11 through early May 12, triggered a lahar consisting of hyperconcentrated flow (close to the transition to debris flow). That lahar steadily deposited sediment within the leveed channel in Chaitén town and aggraded the river bed to about $4.5 \mathrm{~m}$ above its original level (Fig. 7). Lahar discharge waned during the subsequent $\sim 14$-h rainfall hiatus ( 0700-2100 hours on May 12), and the waning flow incised some of this fresh fill, leaving uneven surfaces on type A deposits in different stratigraphic sections (Fig. 7). The lahar may have been preceded by other flow types (streamflow or debris flow), but the earliest deposits in the sequence were not exposed at the time of fieldwork for this study. A second $60-\mathrm{mm}$ pulse of rainfall (pulse 2; Fig. 3b) started in the late evening of May 12 and continued through most of May 13. It generated an additional $\sim 2 \mathrm{~m}$ of aggradation consisting mostly of type B deposits. A third pulse of rainfall (pulse 3; Fig. 3b) began around midnight on May 14. The first $50-60 \mathrm{~mm}$ of that pulse resulted in more dilute flood flow, which by about midday had caused an additional half meter of aggradation that consisted of type $\mathrm{C}$ deposits (the only type found in overbank deposits) and triggered channel avulsion through the town and some fluvial reworking of the top meter of channel fill. 


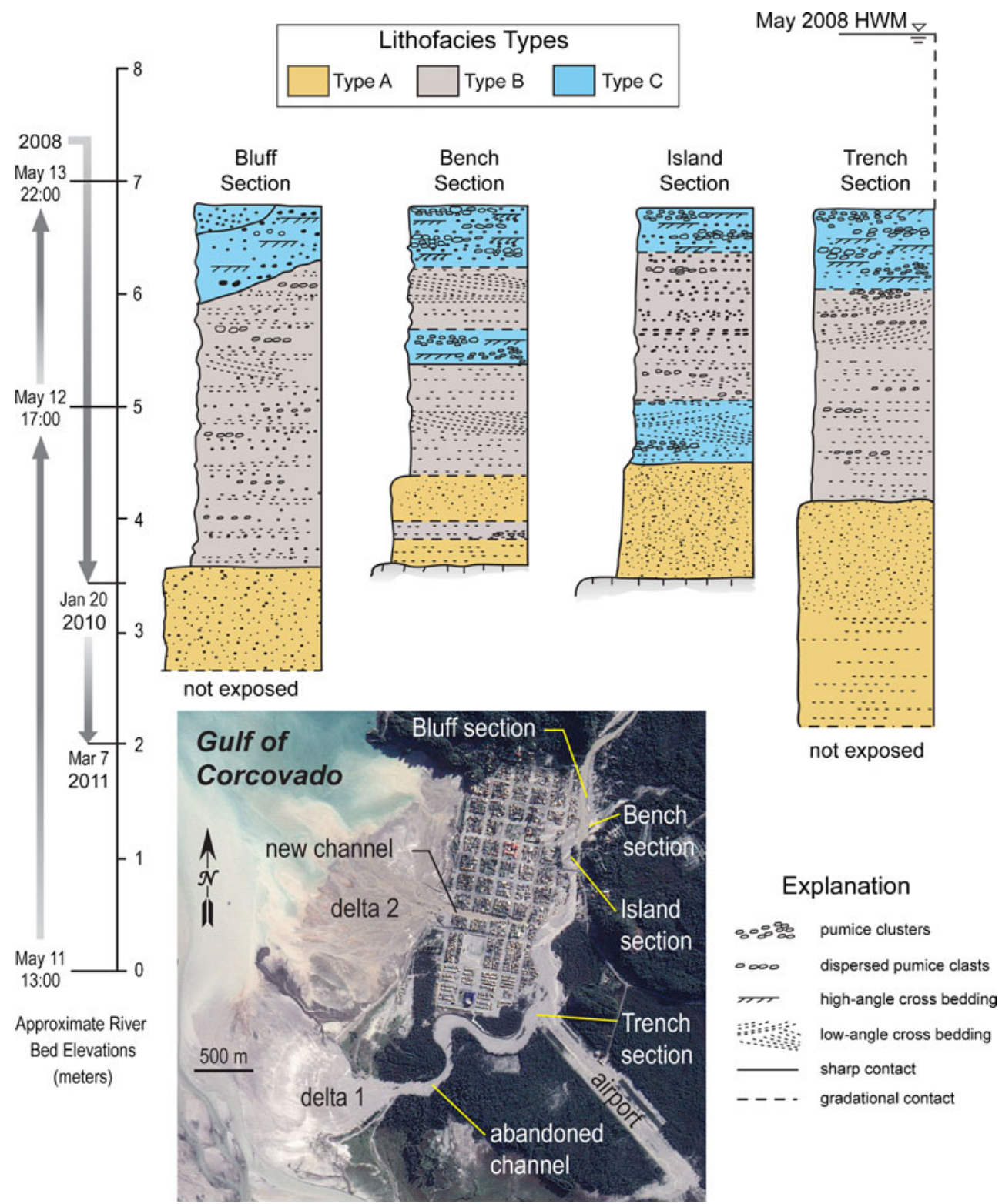

Fig. 7 Scaled schematic stratigraphic sections recording aggradation along lower Chaitén River channel adjacent to Chaitén town. Flow direction from left to right in section sequence. See Fig. 6 for lithofacies images and process interpretations. Channel bed elevations (estimated $\pm 0.5 \mathrm{~m}$ ) at different times show a nearly completed aggradation-degradation cycle by early 2011 (depicted by arrows on left). Section locations are shown beneath in the Formosat satellite image (May 26, 2008; NASA Earth

Alternating lithofacies types in the middle parts of two of the stratigraphic sections (Fig. 7) suggest some complexity in deposition during the flood phase of the laharflood event. The appearance of type $\mathrm{C}$ deposits locally within a predominantly type B depositional sequence can be best explained by lateral shifting of one or more thalwegs, probably with some concurrent fluctuation of flood sediment concentration. Such shifting resulted in superposition of sediment deposited by aggrading flows of varying flow depth, velocity, and sediment concentration.
Observatory). Note that the lowermost $\sim 3 \mathrm{~km}$ of river channel were filled with sediment and abandoned when the river avulsed through town. A small delta (delta 1) formed at the original river mouth prior to avulsion; a larger second delta (delta 2) formed at new river mouth. Delta 1 (about $1 \mathrm{~km}^{2}$ in area) is surrounded by delta sediment deposited by the Yelcho and Negro Rivers, not in view. $H W M$ high-water mark

This interpretation is supported by aerial photographs of the valley-fill deposit in the lower $3 \mathrm{~km}$ of the river (the reach abandoned due to channel avulsion), which show a complex braided channel pattern with multiple shallow thalwegs. Assumed fluctuation in sediment concentration between hyperconcentrated flow and streamflow, at least locally in the channel, is supported by clear sedimentological evidence of hyperconcentrated-flow deposits overlying fluvial deposits in the Island Section (Fig. 7). Such concentration fluctuations in rainfall-generated floods at volcanoes have 
been reported in at least one other case (Lavigne and Suwa 2004).

Tephra and flood-deposit volumes

On the basis of tephra deposit thicknesses measured in 2009 (Alfano et al. 2011) and in 2010 (this study), we estimate that a minimum of $20 \times 10^{6} \mathrm{~m}^{3}$ of tephra was delivered to the Chaitén River drainage basin by the eruption. Most of that tephra was deposited in the East Fork sub-basin (Fig. 1). On the basis of observed (January 2010) ash pedestals up to $15 \mathrm{~cm}$ tall preserved beneath leaves, branches, and pieces of tree bark at numerous locations in adjacent watersheds (Fig. 2c), we conclude that a significant but unknown amount of the original tephra blanket (probably $\geq 10 \mathrm{~cm}$ ) was eroded before measurements of tephra sections were made. Similar observations of surface erosion of tephra have been made, for example, at Usu volcano (Yamakoshi et al. 2002). A significant volume of tephra also fell within the caldera, also part of the Chaitén drainage basin, but it remained largely trapped there and is not considered in this analysis.

At least $3-8 \times 10^{6} \mathrm{~m}^{3}$ of rain-mobilized sediment filled the main stem Chaitén River valley. This estimate is based on the observation that 7.5 to $9.5 \mathrm{~km}$ of channel $(50-75 \mathrm{~m}$ wide) was filled with 5 to $7 \mathrm{~m}$ of 2008 lahar-flood deposit, which totals $2-5 \times 10^{6} \mathrm{~m}^{3}$; at a site visited in the steeper East Fork channel, there was relatively little deposition $(\sim 30 \mathrm{~cm})$. In addition, an estimated minimum of $1-3 \times 10^{6} \mathrm{~m}^{3}$ was deposited in the original Chaitén River delta (delta 1 in Fig. 7), where deposition occurred prior to channel avulsion on May 14 or 15 . This combined minimum flow-deposit volume represents removal of $15-40 \%$ of the minimum tephra volume deposited in the drainage basin, a range that overlaps with fractions of tephra blankets eroded at some other volcanoes. For example, at Usu volcano (Japan) and Mount St. Helens (USA) 10-20\% of the tephra volumes deposited from eruptions in 1977-78 and 1980, respectively, were eroded within 1-4 years (Kadomura et al. 1983; Chinen 1986; Collins and Dunne 1986), whereas over similar time frames as much as 30-50 \% of newly deposited tephra was eroded at Parícutin (México) and Irazú (Costa Rica) volcanoes (Segerstrom 1950; Waldron 1967). It is noteworthy that the substantial fractional amount of tephra eroded at Chaitén occurred in less than a week, whereas comparable fractions took months to years to erode at other volcanoes, even at those in subtropical and tropical climates.

\section{Damage to Chaitén town}

The flood levee separating Chaitén town from the Chaitén River was overtopped in numerous locations on May 13 and 14, and it continued to be overtopped at least through May
20. Sediment-charged flood water surged down nearly every street in the town and deposited multiple layers of sand and silt that inundated buildings, vehicles, and infrastructure in up to $3 \mathrm{~m}$ of sediment (Fig. 5). Most buildings were simply buried in 1 to $2 \mathrm{~m}$ of mud and sand, although damages included direct impact by floating debris and lifting of some buildings off their foundations. The terminal building at the airport was encased in up to $1 \mathrm{~m}$ of sediment and the entire runway was buried, resulting in closure and relocation of the airport to a new site several kilometers to the north.

Following abandonment of the lower $3 \mathrm{~km}$ of the Chaitén River channel between May 14 and 15, several new channels were established, having begun by river flow being diverted westward down paved streets (Fig. 5). Waterfalls up to $7 \mathrm{~m}$ high formed where flow spilled off the edge of the terrace upon which the town was built and into Chaitén Bay (Fig. 5d). By May 26, these waterfalls began migrating upstream as material in the headcuts was eroded and capping slabs of pavement collapsed down to the lower level (Fig. 5d). SERNAGEOMIN overflight photographs show that, by June 3, the knickpoint waterfall on the primary avulsion channel had retreated nearly $800 \mathrm{~m}$ headward and degraded into rapids, and that the channel had partially infilled and widened $300-400 \%$. As this new channel widened, buildings, vehicles, and other debris toppled into the river, and a number of vehicles and a few houses were transported out onto a rapidly growing new delta (delta 2 in Fig. 7).

\section{Discussion}

Erosion and mobilization of tephra in response to the May 11-12 rainfall appears to have been extraordinarily efficient, but water and sediment volumes are difficult to quantify precisely. An assumed geometry of the lahar deposit in the pre-eruption river channel (4 $\mathrm{m}$ average thickness, 4,000$5,000 \mathrm{~m}$ length, $50 \mathrm{~m}$ average width) yields an estimated lahar deposit volume of approximately $0.8-1 \times 10^{6} \mathrm{~m}^{3}$. We further assume that it comprises most of the tephra eroded from the basin and delivered to the Chaitén River channel during the first storm pulse following substantial deposition of fine tephra. If the average volumetric solids fraction of this lahar had been about 0.50 (about the threshold between hyperconcentrated flow and debris flow, which was assessed from deposit sedimentology), $0.8-1 \times 10^{6} \mathrm{~m}^{3}$ of runoff would have been required to mobilize the lahar. If $20 \mathrm{~mm}$ of rain fell on the $77-\mathrm{km}^{2}$ catchment during the first storm pulse with a runoff coefficient of 1.0 (no infiltration or other storage), the resulting runoff volume would have been about $1.5 \times 10^{6} \mathrm{~m}^{3}$. If $25 \mathrm{~mm}$ fell, slightly more than was recorded at any of the region's five rain gauges (Table 1), runoff volume with no infiltration would have been $1.9 \times$ $10^{6} \mathrm{~m}^{3}$. If the runoff coefficient for the fresh Chaitén ash 
was $0.75-0.9$, as has been reported elsewhere for moderateintensity rain on fresh, fine ash (Waldron 1967; Leavesley et al. 1989; Yamakoshi et al. 2005), runoff volume from the Chaitén River catchment during pulse 1 could have been 1$1.7 \times 10^{6} \mathrm{~m}^{3}$ - perhaps up to two times the volume of mobilized sediment. Although the quantities used in this analysis have large uncertainties (perhaps to $50 \%$ ), the analysis implies that the rainfall in pulse 1 was highly efficient at eroding and mobilizing tephra. Several factors likely contributed to this highly efficient hydrologic response and sediment delivery (discussed below): (1) a greatly reduced hillslope infiltration capacity and increased runoff owing to fine to extremely fine ash cover, (2) the thickness of the fine ash layers, (3) the very steep $\left(35^{\circ}-70^{\circ}\right)$ slopes in the drainage basin, and (4) enhanced hillslope erosion due to entrainment of ash in the runoff.

Infiltration capacity of the ground surface is key for runoff production. Fresh surficial ash layers rich in very fine to extremely fine ash $(<0.125 \mathrm{~mm})$ can reduce infiltration capacities on forested hillslopes by orders of magnitude to rates as low as $2 \mathrm{~mm} / \mathrm{h}$ (Murata and Okabayashi 1983; Leavesley et al. 1989) and increase runoff coefficients (the fraction of precipitation that is surface runoff) to more than 0.90 (Leavesley et al. 1989). Conversely, hillslopes covered in coarse tephra can be so permeable that virtually all rainfall infiltrates and no surface runoff ever occurs (Yamakoshi et al. 2005). Surface runoff occurs when infiltration capacity is exceeded by rainfall intensity, and significant runoff clearly occurred in the Chaitén drainage basin. Yet the maximum 30-min intensity measured at Huinay on May 11-12 (the only station recording rainfall intensity) was only $3 \mathrm{~mm} / \mathrm{h}$, which would be barely enough to produce runoff if infiltration capacity were $2-5 \mathrm{~mm} / \mathrm{h}$, as was reported for fresh ash at Mount St. Helens (Leavesley et al. 1989). The acute sedimentation response observed on May 11-12 suggests that either rainfall intensity at Chaitén was substantially greater than that at Huinay $(60 \mathrm{~km}$ to the north) or that infiltration capacity was less than $2 \mathrm{~mm} / \mathrm{h}$. Both are possible, given the sparse rain-gauge network, the distance to the Huinay rain gauge, and the lack of information about the ash layers that were initially rained on (and since eroded away) within the Chaitén drainage basin. Whatever the reason, the ratio of surface runoff to total rainfall during the initial $\sim 20 \mathrm{~mm}$ rainfall on May 11-12 had to have been very high to produce a $10^{6}-\mathrm{m}^{3}$ lahar and nearly $5 \mathrm{~m}$ of downstream channel aggradation.

Thickness of fine ash is important because it can prolong low infiltration capacities and high runoff rates. The combined thickness of tephra layers containing fine to extremely fine ash was $>10 \mathrm{~cm}$ in much of the Chaitén basin prior to the onset of rain on May 11 (Figs. 1 and 2a), which kept infiltration rates low even as rills cut downward into the tephra blanket (Fig. 2b). If capping layers of impermeable ash had been thin, surface runoff would have quickly incised through them and infiltration capacities would have increased substantially once coarser underlying ash layers had been exposed (e.g., Major and Yamakoshi 2005). Thick fine-grained ash layers also contributed to damaging rain-triggered lahars and floods at Irazú volcano during its 1963-1965 eruption (Murata et al. 1966; Waldron 1967).

Flowing water increases in erosive power as it increases in sediment concentration, and flowing hyperconcentrated sediment-water mixtures are particularly erosive (Xu 1999). Suspension of particles finer than $0.063 \mathrm{~mm}$ at concentrations $>8$ volume percent is generally required for transition to hyperconcentrated flow in mixed-size sediment (Pierson 2005), and the abundance of fines in the ash mantle suggests that ash suspended in hillslope runoff played an important role in enhancing hillslope erosion and sediment delivery to the Chaitén River. This argument is supported by a field study in which a surface ash layer, composed of $90 \%$ particles $<0.1 \mathrm{~mm}$, was shown to increase the rate of sediment entrainment in overland runoff by as much as 50 times in comparison to the rate on a bare slope prior to ash deposition (Ogawa et al. 2007).

The fine grain size (dominantly $<0.25 \mathrm{~mm}$ ) in the upper layers of the ash blanket and the thickness of those upper layers therefore must have been largely responsible for the types of hydrologic and sedimentation responses observed in the Chaitén River drainage basin. From tephra dispersal maps, fine-grained tephra layers J-M of Alfano et al. (2011), and perhaps some of the earlier-deposited ash, likely formed these layers. Although we have not attempted to quantify the role of slope angle, $83 \%$ of the basin is composed of steep sloping terrain, mostly steeper than $35^{\circ}$; therefore, these steep slopes had to have played a role in enhancing runoff and erosion of the ash blanket.

Factors considered important for triggering disproportionately large sedimentation responses at other volcanoes following soon after deposition of fine ash (by tephra fall or pyroclastic density currents) were much less important or not operative at Chaitén in 2008. For example, triggering of lahars and flash floods at Usu volcano, Japan (Kadomura et al. 1983), Soufrière Hills volcano, Montserrat (Alexander et al. 2010), and Colima volcano, México (Capra et al. 2010) by small rainstorms $(20-30 \mathrm{~mm},<30 \mathrm{~mm}$, and $<10 \mathrm{~mm}$ total rainfall, respectively) has been attributed to formation of a mortar-like ash crust (Usu) to extensive vegetation damage that eliminated rainfall interception (Montserrat) and to ground-surface hydrophobicity due to deposition of organic waxes and resins on hillslopes heavily vegetated by pines and other conifer tree species (Colima).

Formation of a surface crust on ash deposited between early May 6 and midday on May 11 is unlikely because substantial rain is required to form a crust, either through surface sealing and densification by energetic raindrop 
impact (Segerstrom 1950; Fohrer et al. 1999) or upward wicking and evaporative precipitation of soluble salts (Waldron 1967). The Chaitén River lahar was triggered by the first rain to fall, more than intermittent mist or light drizzle ( $\sim \mathrm{mm}$ in 5 days), following May 6-11 ash deposition (Table 1), and that trace precipitation would have been incapable of forming a crust by either of the abovementioned mechanisms. A crust conceivably could have formed on ash deposited prior to May 6 by the May 4-6 rain, but it would have been buried by tephra falling between May 6 and May 11. Had such a buried crust existed, its effect on runoff would have supplemented the effects of the very fine surface layers of ash, but only once those surface layers eroded away.

Loss of canopy interception from eruption-induced vegetation damage was not an important factor, because vegetation was severely damaged only within a small area of the basin close to the caldera rim (Fig. 2b). Although some limb breakage by the weight of tephra accumulating in tree canopies was noted in other areas (Swanson et al. 2013), canopy foliage remained largely intact in most of the basin for weeks to months after the eruption. Thus, rainfall interception by forest vegetation within the basin was altered very little at the time of the lahar and flood.

Development of a hydrophobic layer on the tephra surface is highly unlikely because there was not enough time for hydrophobic organic compounds such as resins to accumulate beneath the trees and rain forest tree species in this region are poor in such compounds (C. Crisafulli, 2012, U.S. Forest Service, personal communication).

An important and remaining question is why the May 4-6 rainstorm, which delivered more rain at higher intensities than pulse 1 on May 11-12, did not elicit notable sediment delivery to the river channel. We see two possible reasons: (1) early tephra fall prior to and during the May 4-6 storm was relatively coarse in much of the Chaitén basin (Fig 2b) and thus had a higher infiltration capacity than subsequently deposited finer ash, and (2) the dense forest canopy and understory vegetation could have intercepted some of the fine-grained components of the early tephra fall (wet fine ash easily sticks to leaf surfaces). However, uncertain timing of the earliest tephra falls, especially the fine ash falls, relative to onset of rainfall hinders our understanding of the lack of response to this early syneruptive rain. The highly efficient production of runoff observed at Chaitén on May 11-12, in contrast, was achieved by deposition of sufficiently thick layers of fine to extremely fine ash in the Chaitén basin, emplaced after May 6 and perhaps augmented by a buried crust that may have formed during rainfall on May 4-6 and been reexposed during erosion of the tephra blanket.

\section{Conclusions}

Highly efficient runoff production during a series of small rainstorms, occurring within days of heavy tephra fall in the Chaitén River drainage basin, produced a lahar-flood that transported an extraordinary volume of volcanic sediment downstream in only a few days. The lahar-flood event consisted of an initial lahar (predominantly hyperconcentrated flow), followed closely by two substantial surges of muddy floodwater. The stage was set for this acute sedimentation response by the explosive phase of the 2008-2009 eruption of Chaitén volcano, which mantled the steep slopes of the 77$\mathrm{km}^{2}$ Chaitén River drainage basin with a 0.03 - to 1 -m-thick sequence of tephra, the upper 40-50\% of which was composed predominantly of fine to extremely fine ash $(0.25$ to $<0.063 \mathrm{~mm}$ ). Several aspects of this lahar-flood and the sediment it deposited are noteworthy:

1. The initial lahar was triggered by $\sim 20 \mathrm{~mm}$ of total rainfall falling over about $24 \mathrm{~h}$ at apparent 30-min intensities of $\leq 3 \mathrm{~mm} / \mathrm{h}$ - a modest lahar-triggering rainfall but one not unprecedented on volcanoes following extensive fine ash deposition. The lahar produced $\sim 4.5 \mathrm{~m}$ of channel aggradation in the Chaitén River $10 \mathrm{~km}$ downstream from the volcano within $24 \mathrm{~h}$ of rain onset.

2. Runoff from two subsequent closely spaced storm pulses (dropping $\sim 120 \mathrm{~mm}$ of rain) generated two additional surges in a complex muddy flood (initially bordering on hyperconcentrated flow then becoming more dilute) that followed the lahar by about half a day and lasted about $36 \mathrm{~h}$. This flood caused an additional $\sim 2.5 \mathrm{~m}$ of aggradation in the channel, extensive flooding in Chaitén town, and avulsion of the lower $3 \mathrm{~km}$ of the Chaitén River.

3. The lahar, estimated to be about $10^{6} \mathrm{~m}^{3}$ in volume, was confined to the channel; overbank flooding and damage to the town were accomplished by later muddy floodwater and fluvial deposition.

4. At least $3-8 \times 10^{6} \mathrm{~m}^{3}$ of remobilized tephra were delivered to the Chaitén River channel-roughly 15-40\% of the minimum tephra volume that mantled drainage basin hillslopes.

5. Factors responsible for the highly efficient rainfall runoff and the rapid downstream sedimentation appear to be the emplacement of sufficiently thick and highly impermeable fine to extremely fine ash throughout the basin and the steepness of the basin slopes. Other possible factors such as a hydrophobic surface layer or large-scale destruction of rain-intercepting vegetation did not play a role.

6. After only a few weeks, sediment production from the basin waned and incision of the channel fill began, probably owing to rapid stabilization of the ash mantle 
in response to continued heavy rainfall. Hence, the time lag between basin disturbance and maximum level of aggradation by lahars and subsequent fluvial sedimentation can be very brief.

Our observations support previous findings that tephra fall involving large quantities of fine-grained ash can radically alter a basin's hydrologic regime and sediment delivery, at least transiently. They also reinforce that hydrologic hazards indirectly associated with eruptions can have consequences more severe than direct eruption impacts. Our findings emphasize two concepts that are probably not widely known by emergency managers: (1) hazardous mobilization of sediment can be triggered by unremarkable amounts of rainfall, and (2) deleterious impacts from raintriggered lahars and syneruptive fluvial sedimentation can occur very soon after rain starts falling on fresh tephra, possibly faster than a community can be evacuated. Proximal valley communities downstream of volcanoes are vulnerable to volcanically augmented floods, as well as high-concentration lahars.

Acknowledgments Assistance in data collection from Dagoberto Guzman (Parque Pumalín), Reinhard Fitzek (Fundación Huinay), Nicolás LaPenna (Chaitur Excursiones, Chaitén), and Fred Swanson (U.S. Forest Service) is gratefully acknowledged. Helpful reviews of early versions of this manuscript were provided by Karen Gran, Chris Newhall, Gordon Grant, Vern Manville, and three anonymous reviewers.

Open Access This article is distributed under the terms of the Creative Commons Attribution License which permits any use, distribution, and reproduction in any medium, provided the original author(s) and the source are credited.

\section{References}

Alexander J, Barclay J, Susnik J, Loughlin SC, Herd RA, Darnell A, Crosweller S (2010) Sediment-charged flash floods on Montserrat: the influence of synchronous tephra fall and varying extent of vegetation damage. J Volcanol Geotherm Res 194:127-138

Alfano F, Bonadonna C, Volentik ACM, Connor CB, Watt SFL, Pyle DM, Connor LJ (2011) Tephra stratigraphy and eruptive volume of the May, 2008, Chaitén eruption, Chile. Bull Volcanol 73:613-630

Alfano F, Bonadonna C, Gurioli L (2012) Insights into eruption dynamics from textural analysis: the case of the May, 2008, Chaitén eruption. Bull Volcanol 74:2095-2108. doi:10.1007/s00445-012-0648-3

Barclay J, Alexander J, Sŭsnik J (2007) Rainfall-induced lahars in the Belham Valley, Montserrat, West Indies. J Geol Soc Lond 164:815-827

Capra L, Borselli L, Varley N, Gavilanes-Ruiz JC, Norini G, Sarocchi D, Caballero L, Cortes A (2010) Rainfall-triggered lahars at Volcán de Colima, Mexico-surface hydro-repellency as initiation process. J Volcanol Geotherm Res 189:105-117

Carn SA, Pallister JS, Lara L, Ewert JW, Watt S, Prata AJ, Thomas RJ, Villarosa G (2009) The unexpected awakening of Chaitén volcano, Chile. Eos Trans Am Geophys Union 90:205-206

Castro JM, Dingwell DB (2009) Rapid ascent of rhyolitic magma at Chaitén volcano, Chile. Nature 461:780-784
Chinen T (1986) Surface erosion associated with tephra deposition on Mt. Usu and other volcanoes. Environ Sci Hokkaido 9(1):137-149

Collins BD, Dunne T (1986) Erosion of tephra from the 1980 eruption of Mount St. Helens. Geol Soc Am Bull 97:896-905

Durant AJ, Villarosa G, Rose WI, Delmelle P, Prata AJ, Viramonte JG (2012) Long-range volcanic ash transport and fallout during the 2008 eruption of Chaiten volcano, Chile. Phys Chem Earth 45-46:50-64

Fohrer N, Berkenhagen J, Hecker JM, Rudolph A (1999) Changing soil and surface conditions during rainfall-single rainstorms/ subsequent rainstorms. Catena 37:355-375

Folk RL (1980) Petrology of sedimentary rocks. Hemphill, Austin

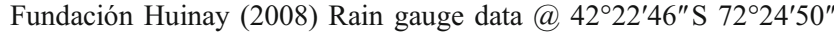
W, 15m. http://www.huinay.cl/. Accessed 20 Feb 2010

Garreaud RD (2009) The Andes climate and weather. Adv Geosci 22:3-11

Gran KB, Montgomery DR, Halbur JC (2011) Long-term elevated post-eruption sedimentation at Mount Pinatubo, Philippines. Geology 39:367-370

Harms JC, Mackenzie DB, McCubbin DG (1963) Stratification in modern sands of the Red River, Louisiana. J Geol 71:566-580

Hayes SK, Montgomery DR, Newhall CG (2002) Fluvial sediment transport and deposition following the 1991 eruption of Mount Pinatubo. Geomorphol 45:211-224

Ikeya H, Hendrayanto KK, Mizuymama T (1996) Observed changes in infiltration rates of pyroclastic deposits resulting from volcanic activities. Japan Soc Eros Control Eng Publ 19:27-31

Imagawa T (1986) Mud and debris flows on Mt. Usu after the 19771978 eruption. Environ Sci Hokkaido 9(1):113-135

Kadomura H, Imagawa T, Yamamoto H (1983) Eruption-induced rapid erosion and mass movements on Usu Volcano, Hokkaido. Zeitsch Geomorph Suppl Bd 46:123-142

Lara LE (2009) The 2008 eruption of the Chaiten Volcano, Chile: a preliminary report. Andean Geol 36:125-129

Lara LE, Moreno R, Amigo Á, Hoblitt RP, Pierson TC (2013) Late Holocene history of Chaiten Volcano: new evidence for a 17thcentury eruption. Andean Geology 40(2): in press

Lavigne F, Suwa H (2004) Contrasts between debris flows, hyperconcentrated flows and stream flows at a channel of Mount Semeru, East Java, Indonesia. Geomorphol 61:41-58

Lavigne F, Thouret JC, Voight B, Suwa H, Sumaryono A (2000) Lahars at Merapi volcano, Central Java: an overview. J Volcanol Geotherm Res 100:423-456

Leavesley GH, Lusby GC, Lichty RW (1989) Infiltration and erosion characteristics of selected tephra deposits from the 1980 eruption of Mount St. Helens, Washington, USA. Hydrol Sci J 34:339-353

Major JJ (2004) Posteruption suspended-sediment transport at Mount St. Helens-decadal-scale relationships with landscape adjustments and river discharges. J Geophys Res 109:F01002. doi:10.1029/2002JF000010

Major JJ, Janda RJ, Daag AS (1996) Watershed disturbance and lahars on the east side of Mount Pinatubo during the midJune 1991 eruptions. In: Newhall CG, Punongbayan RS (eds) Fire and mud-eruptions and lahars of Mount Pinatubo, Philippines. Philippine Institute of Volcanology and Seismology, Quezon City, and University of Washington Press, Seattle: $895-919$

Major JJ, Mark LE (2006) Peak flow responses to landscape disturbances caused by the cataclysmic 1980 eruption of Mount. St. Helens, Washington. Geol Soc Am Bull 118:938-958

Major JJ, Pierson TC, Dinehart RL, Costa JE (2000) Sediment yield following severe volcanic disturbance - a two-decade perspective from Mount St. Helens. Geology 28:819-822

Major JJ, Yamakoshi T (2005) Decadal-scale change of infiltration characteristics of a tephra-mantled hillslope at Mount St. Helens, Washington. Hydrol Processes 19:3621-3630

McKee ED, Crosby EJ, Berryhill HL Jr (1967) Flood deposits, Bijou Creek, Colorado, June 1965. J Sed Pet 37:829-851 
Miyabuchi Y (1999) Deposits associated with the 1990-1995 eruption of Unzen volcano, Japan. J Volcanol Geotherm Res 89:139-158

Murata H, Okabayashi T (1983) The erosion and failure of the volcanic ash slopes of Sakurajima. Tech Rpts Yamaguchi Univ 3:141-149

Murata KJ, Dondoli C, Saenz R (1966) The 1963-65 eruption of Irazú volcano (the period of March 1963 to October 1964). Bull Volcanol 29:765-796

Newhall CG, Punongbayan RS (eds) (1996) Fire and mud-eruptions and lahars of Mount Pinatubo, Philippines. Philippine Institute of Volcanology and Seismology, Quezon City, and University of Washington Press, Seattle

Ogawa Y, Daimaru H, Shimizu A (2007) Experimental study of posteruption overland flow and sediment load from slopes overlain by pyroclastic-flow deposits, Unzen volcano, Japan. Géomorphologie Relief Proc Environ 3:237-246

Osores MS, Folch A, Collini E, Villarosa G, Durant A, Pujol G, Viramonte JG (2013) Validation of the FALL3D model for the 2008 Chaitén eruption using field and satellite data. Andean Geology 40(2): in press

Pallister JS, Diefenbach A, Burton W, Muñoz J, Griswold J, Lara L, Lowenstern J, Valenzuela C (2013a) The Chaitén rhyolite lava dome: eruption sequence, lava dome volumes, rapid effusion rates and source of the rhyolite magma. Andean Geol 40(2): in press

Pallister JS, Schneider DJ, Griswold JP, Keeler RH, Burton WC, Noyles C, Newhall CG, Ratdomopurbo A (2013b) Merapi 2010 eruption - chronology and extrusion rates monitored with satellite radar and used in eruption forecasting. J Volcanol Geotherm Res (in press)

Pierson TC (2005) Hyperconcentrated flow-transitional process between water flow and debris flow. In: Jakob M, Hungr O (eds) Debris-flow hazards and related phenomena. Springer-Praxis, Chichester, pp 159-202

Pierson TC, Scott KM (1985) Downstream dilution of a lahar: transition from debris flow to hyperconcentrated streamflow. Water Resour Res 21:1511-1524

Pierson TC, Pringle PT, Cameron KC (2011) Magnitude and timing of downstream channel aggradation in response to a dome-building eruption at Mount Hood, Oregon. Geol Soc Am Bull 123:3-20

Rodolfo KS, Arguden T (1991) Rain-lahar generation and sedimentdelivery systems at Mayon Volcano, Philippines. In: Fisher RV, Smith GA (eds) Sedimentation in volcanic settings. SEPM Spec Pub 45:71-87

Rodolfo KS, Umbal JV, Alonso RA, Remotigue CT, Paladio-Melosantos ML, Salvador JHG, Evangelista D, Miller Y (1996) Two years of lahars on the western flank of Mount Pinatubo - initiation, flow processes, deposits, and attendant geomorphic and hydraulic changes. In: Newhall CG, Punongbayan RS (eds) Fire and mud-eruptions and lahars of Mount Pinatubo, Philippines. Philippine Institute of Volcanology and Seismology, Quezon City, and University of Washington Press, Seattle: 989-1013

Scott KM (1988) Origins, behavior, and sedimentology of lahars and lahar-runout flows in the Toutle-Cowlitz River system. US Geol Surv Prof Paper 1447-A

Segerstrom K (1950) Erosion studies at Parícutin, State of Michoacán, Mexico. U.S. Geol Surv Bull 965-A
SERNAGEOMIN (2002) Mapa Geológico de Chile. Servicio Nacional de Geología y Minería, Carta Geológica de Chile, Serie Geología Básica No. 75, 1 mapa en 3 hojas, escala 1:1,000,000. Santiago

SERNAGEOMIN (2008a) Erupción del Volcan Chaitén, Tercer Informe Técnico, 07 de Mayo de 2008. OVDAS-SERNAGEOMIN. Servicio Nacional de Geología y Minería, Santiago

SERNAGEOMIN (2008b) Erupción del Volcan Chaitén, Décimo Primer Informe Técnico, 16-20 de Mayo de 2008. OVDASSERNAGEOMIN. Servicio Nacional de Geología y Minería, Santiago

Simons DB, Richardson EV, Nordin CF Jr (1965) Sedimentary structures generated by flow in alluvial channels. Soc Econ Paleon Min Spec Pub 12:34-52

Smith GA (1986) Coarse-grained nonmarine volcaniclastic sediment: terminology and depositional process. Geol Soc Am Bull 97:1-10

Smith GA, Lowe DR (1991) Lahars: volcano-hydrologic events and deposition in the debris flow-hyperconcentrated flow continuum. In: Fisher RV, Smith GA (eds) Sedimentation in volcanic settings. SEPM Spec Pub 45:59-70

Smith ND (1970) The braided stream depositional environment: comparison of the Platte River with some Silurian clastic rocks, northcentral Appalachians. Geol Soc Am Bull 81:2993-3014

Smith ND (1971) Pseudo-planar stratification produced by very low amplitude sand waves. J Sed Pet 41:69-73

Smith RB, Evans JP (2007) Orographic precipitation and water vapor fractionation over the Southern Andes. J Hydrometeorol 8:3-19

Swanson FJ, Major JJ (2005) Physical events, environments, and geological-ecological interactions at Mount St. Helens-March 1980-2004. In: Dale VH, Swanson FJ, Crisafulli CM (eds) Ecological responses to the 1980 eruption of Mount St. Helens. Springer, New York, pp 27-44

Swanson FJ, Jones JA, Crisafulli CM, Lara A (2013) Effects of volcanic and hydrologic processes on forest vegetation, Chaitén Volcano, Chile. Andean Geol 40(2): in press

Thouret JC, Abdurachman KE, Bourdier JL, Bronto S (1998) Origin, characteristics, and behavior of lahars following the 1990 eruption of Kelud volcano, eastern Java (Indonesia). Bull Volcanol 59:460-480

Waldron HH (1967) Debris flow and erosion control problems caused by the ash eruptions of Irazu volcano Costa Rica. US Geol Surv Bull 1241-I

White JDL, Houghton BF (2006) Primary volcaniclastic rocks. Geology 34:677-680

Williams PF, Rust BR (1969) The sedimentology of a braided river. J Sed Pet 39:649-679

Xu J (1999) Erosion caused by hyperconcentrated flow on the Loess Plateau of China. Catena 36:1-19

Yamakoshi T, Suwa H (2000) Post-eruption characteristics of surface runoff and sediment discharge on the slopes of pyroclastic-flow deposits, Mount Unzen, Japan. Trans Jap Geomorph Union 21:469-497

Yamakoshi T, Doi Y, Osanai N (2005) Post-eruption hydrology and sediment discharge at the Miyakejima volcano, Japan. Z Geomorph NF Suppl Vol 140:55-72

Yamakoshi T, Ishida T, Nakano M, Yamada T (2002) Characteristics of sediment movement phenomena caused by rainfall after the 2000 eruption of Usu volcano. INTERPRAEVENT 2002 in the Pacific Rim-Matsumoto, Japan. Congress Pub 1:145-151 